\title{
Students' Self-Esteem of the First Year English Education Study Program in STKIP Muhammadiyah Kotabumi
}

\author{
Elis Susanti ${ }^{1}$ \\ Program Studi Pendidikan Bahasa Inggris STKIP Muhammadiyah Kotabumi
}

\begin{abstract}
Abstrak
Self-Esteem (nilai diri) merupakan salah satu aspek dalam diri siswa yang berada pada ranah afektif (psikologi). Self-esteem merupakan aspek yang penting untuk diukur atau diketahui karena merupakan suatu persepsi tentang bagaimana seseorang memberikan penilaian terhadap dirinya sendiri. Dengan mengetahui bagaimana nilai yang diberikan siswa kepada diri mereka sendiri, guru akan mampu lebih selektif dalam menerapkan strategi pembelajaran agar mampu mencapai hasil yang maksimal dalam proses pembelajaran. Penelitian ini adalah penelitian deskriptif kuantitatif yang bertujuan mendeskripsikan bagaimana self-esteem (nilai diri) mahasiswa tahun pertama Program Studi Pendidikan Bahasa Inggris di STKIP Muhamamadiyah Kotabumi terhadap 50 orang mahasiswa sebagai sampel yang diambil secara acak menggunakan teknik simple random sampling. Data dalam penelitian ini dikumpulkan menggunakan angket yang disusun dengan skala Likert untuk selanjutnya dianalisis dan dikategorisasikan. Hasil penelitian menunjukkan bahwa 28\% mahasiswa memiliki self-esteem yang tinggi, 66\% mahasiswa dengan kategori sedang, dan $6 \%$ siswa memiliki self-esteem yang rendah. Oleh karenanya, disarankan agar dosen yang mengajar pada kelas itu membantu agar mahasiswa tersebut tetap dapat mempertahankan self-esteem (nilai diri) yang positif yang sudah dimiliki serta mampu membantu mahasiswa dengan selfesteem (nilai diri) yang rendah untuk membangunnya menjadi positif atau tinggi melalui penerapan strategi yang relevan.
\end{abstract}

Kata Kunci: Self-Esteem (nilai diri), strategi pembelajaran, afektif

\section{Background}

Students' achievement in a learning process is determined by many factors. The two broad factors which have been familiar are the factors coming within the students (internal facors) and those which are outside of the students' themselves (external factors). The internal factors will triger the students to do maximal effort in order to achieve high result in their study. Meanwhile, the external factors can provide positive supports which ease the students to reach their success. Therefore, those factors are both the same important for the students to help them achieve the maximum result in their learning process.

Self esteem, one of the internal factors which also belongs to the affective facet of a student, has been considered as an important factor which can help the students to build positive 
mind about themselves in which then it can maximize the exploration of their potential tallent to achieve success. Since the twenty-first century, the issue about self-esteem is getting more and more popular because of its contribution to human's life. As it is stated by Mruk (2006:2) that talking about self-esteem will involve people with the human's ordinary problems of living like failure, lossess, and the other problems usually faced by many people during their life. In addition, self-esteem also relates to the idea about mentally healthy, successful, and living effectively which deals with the good life of a person. Concequently, it will affect one's living quality in the world as it is stated that low self-esteem causes various mental disorders such as depression, anxiety, and learning problems.

In a learning process, self-esteem is like an individual perception within the students that will be relfected through various behaviors to achieve success. Low or high self-esteem will be reflected though various kinds of attitude and behavior of the students showing their effort to learn successfully. Therefore, the information about students' selfesteem might be much helpfull for the teachers to help them solve many kinds of learning difficulties in the classroom. Moreover, it is known that learning a foreign language involves the students with both linguistics and non-linguistics aspects, it will be a complicated task for the the English teachers as well as lecturers to be more aware of many factors contributing to their students' result of learning including self-esteem.

Refering to the facts showing the essential of self-esteem for one's living quality, it is then encouraged the researcher to investigate how the students' self-esteem of the first year English Education Study Program in STKIP Muhammadiyah Kotabumi through a research entitled "Students" Self-Esteem of the First Year English Education Study Program in STKIP Muhammadiyah Kotabumi”. The objective of the research was to describe how students' self-esteem of the first year students in which the result then can be used as a positive feedback for the lecturers to find and select best strategy and approach which can ease the students to achive best result targeted. In addition, the result of the research can also be used as additional refference for the next researcher who will conduct further research dealing with psychological aspects like self-esteem.

\section{Concept of Self Esteem}

Self-esteem deals with the psychological apects or psychological 
side of the students. It is why the issue about self-esteem will always deal with various aspects of humans' living problems including learning process. Wells and Marwell in Mruk (2006:10) point out the definition of self-esteem as two psychological processes-evaluation and affect. The evaluation process will emphasize more on the role of cognition, while the affect process tend to prioritize the role of feeling. This definition of selfesteem then resulted the typology of definitions consisting of four: self-esteem as a certain attitude which can involve positive or cognitive, emotional, and behavioral reactions; self-esteem as a discrepancy between the self and the one wishes to be; self-esteem as psychological responses a person holds towards himself pr herself, rather than attitude alone; and self-esteem as a part of the self-system in which it deals with one's motivation or self-regulation or both.

In line with the psychological definition of self-esteem by Wells and Marwell, Caunt (2003:1) also defines self-esteem as the value. It is about the value that one places on their life. It is like an individual assessment of themselves about their worth or how worthy they feel about themselves. Caunt states that this value will be affected by the extent to which one considers their living their lives according to aspirations and standards and also by the actions and reactions of other people toward themselves. In conclusion, in his definition of self-esteem Caunt points out thathow one will value themselves or one's individual assessment will be determined by their own standards of living as well as others' behavior toward themselves.

The two explained definions of self-esteem lead to the same conclusion about the definition of self-esteem that self-esteem as a kind of self-evaluation within a human. How one evaluates or assesses themselves or how one sees themselves will determine their selfconcept whether they think they are a capable person or full of failure, whether they are the same worthy as others, whether they will be able to face challenges or not, and many other selfconcepts within one's mind that affect their performance. Therefore, self-esteem really contributing internal aspect within the students that influences their success in learning. As Brown (2000: 145) points out that self-esteem is an important aspect determing the sucessful of cognitive and affective activity. Additionally, Schunk, Pintrich, and Meece (2008:221) also agree that selfesteem contributes to students' success in learning. They state that self-esteem is 
the reason of some students' motivational problems, and poor or law self-esteem will affect the students' learning in the classroom.

Mruk (2006: 152) states that those with high self-esteem will have both positive degree of competence and worthiness. For instance, the people will feel good about themselves in general, feel happy and free to new experiences, feel accepted and acceptable, glad to interact with others, and so on. In contrast, the ones with low self-esteem will lack competence and worthiness in which their behaviors will be in contrast with those who have high self-esteem. In other words, it is concluded that Low self-esteem is usually associated with such things as caution, timidity, lack of initiative, conflict avoidance, insecurity, anxiety, depression, and so forth. In line with Mruk, Plummer (2005:19) states that people with low self-esteem tend to place little value on their abilities and often deny their successes. They find it difficult to set goals and to problemsolve. Self-confidence is reduced and there is an unwillingness to try because of fear of failure. In contrast, the people who believe in themselves and who have developed a degree of self-reliance is more likely to be able to cope with life's inevitable difficulties and failures. They will be able to weather the occasional storm and regain his equilibrium more readily than if self-esteem is low. They will be more able to make informed decisions. They will usually be more willing to try new ways of doing things, learning from mistakes and building confidence for future challenges. They will be able to recognize and develop their specific strengths and cope with changes successfully. They are more likely to enjoy life and form more successful, fulfilling relationships than someone who suffers from acute feelings of lack of self-worth, and they will tend to attract genuine liking and respect from others.

In order to build positive or high self-esteem, knowing the area of selfesteem is necessary to do. Plummer (2005:20) gives seven areas to be developed in order to build and maintain high self-esteem; self-knowledge, self and others, self-acceptance, self-reliance, self-expression, self-confidence, and self-awareness.

First, self-knowledge relates to some attitudes of how a person values themselves. There are many examples of attitude that should be mantained in order to reach high self-esteem like for instance it is essential that a person has a strong sense of self meaning that a person ahould really understand who he or she is and where he or she fits into. 
Besides that, it is also important that a person is able to develop and maintain his or her personal values.

Second, self and others relates to a person's attitudes with regard to their social life or how they relate to others. To maintain high self-esteem, there are some suggested attitudes to be done like being able to suit with others, learning respect and tolerance for other people's views, trying to estimate how might another person see himself or herself, recognizing other people's emotions, and other attitudes which smooth the interaction with other around them.

Third, self-acceptance is about recognizing their own strengths and weaknesses, and keep maintaining their positive attitude toward their weaknesses and bad experience. In order to build high self-esteem, it is suggested to know own strengths and weaknesses, accept when make mistake, receive the physycal appearance condition.

Next, Self-reliance refers to one's belief of their ability to stand on their own feet. These are some activities related to self-reliance that should be developed to maintain high self-esteem: Knowing how to take care of their own seves; understanding that life is often difficult but there are lots of things to to help smooth the path; building a measure of independence and self-motivation; being able to self-monitor and adjust their actions, feelings and thoughts according to realistic assessments of their progress; believing that they have mastery over my life and can meet challenges as and when they arise.

Another area is self expression which relates to one's ability to communicate and interact with others, how they express thoughts using appropriate expression. Several attitude in relation with self-expression to do to build high self-esteem are: understanding how to communicate with each other, not just with words but also through facial expression, body posture, intonation, the clothes we wear, and so forth; learning to read the signals' beyond the words so that they can understand others more successfully and also express themselves more fully and congruently; developing creativity in self-expression; and recognizing and celebrating the unique ways in which they each express who they are.

Self-confidence relates to a person's belief about their ability in doing any task in their life. For instance, knowing that their opinions, thoughts and actions have value and that they have the right to express them; knowing that they have the right to be them and that they make a difference; developing a creative approach to solving problems 
and being confident enough in their own abilities to be able to experiment with different methods of problem-solving and to be flexible enough to alter strategies if needed; being able to accept challenges and to make choices; being secure enough in themselves to be able to develop strategies for coping successfully with the unexpected.

The last is self-awareness which relates to one's ability to manage their own emotional in order to focus on their goal.Several suggested attitudes to do ae as follows: the ability to be focused in the here and now, rather than absorbed in negative thoughts about the past or future including an awareness of their feelings as they arise; knowing what they are capable of, and learning to set realistic yet challenging goals; understanding that emotional, mental and physical change is a natural part of their life; and nderstanding that they have some control in how they change and develop.

In addition to the several areas that are necessary to maintain and build high self-esteem, it also important to know several factors affecting the development of students' self-esteem. It is hoped that knowing those factors will enable both the students themselves and the teachers or lecturers to help enhancing the self-esteem within the students themselves. A previous research investigating the factors affecting students' self-esteem have ever been done by Dhillon et al., (2016:58) entitleld "Factors Influencing Selfesteem of Indian Female Adolescents" revealed several conclusions as follows:

- The role of parents is one of influential factors affecting students' self-esteem development.

- School also plays significant role on students' self-esteem development.

- The role of peers extremely affects students' self-esteem.

- Body-esteem issues is also be the factor affecting students' selfesteem because a feeling of dissatisfaction toward their body's appearance (especially for girls) usually affect their confidence. Moreover, those who are in puberity phase usually give much attention on their body's appearance as well as their peers' body appearance in a relationship.

- Comparison with others in a social interaction also becomes an important factor which will affect students' self-esteem development. 
In line with the result of the previous research explained, Oswalt (2010) emphasizes the social interactions as the factor determining one's evaluation toward themselves. It is for example about how others treat them in a relationship, or what kinds of experience (whether positive or negative) they have ever got during the social interactions with others. In this case, Oswalt also states the importance of parental involvement in giving much more attention on how their children might interact with others in order that they can lead them to build and maintain positif or high self-esteem.

\section{Research Method}

This was a descrptive quantitative research consisting only of one variable-students' self-esteem. The aim of conducting the research is to describe how students' self-esteem of the first year students English Education Study Program in STKIP Muhammadiyah Kotabumi by collecting the research data using a questionnaire of self-esteem. The questionnaire was constructed using Likert scale in which provided several options for each of the items showing the students' perception about certain statements. Meanwhile, the scale in this questionnaire ranged from
$1-5$. The scale of each item for the positive statements had a numerical value as follows:

$$
\begin{array}{ll}
1 & =\text { never } \\
2 & =\text { seldom } \\
3 & =\text { sometime } \\
4 & =\text { often } \\
5 & =\text { always }
\end{array}
$$

In contrast, the scale of each item for the negative statements had a numerical value as follows:

$$
\begin{array}{ll}
5 & =\text { never } \\
4 & =\text { seldom } \\
3 & =\text { sometime } \\
2 & =\text { often } \\
1 & =\text { always }
\end{array}
$$

\begin{tabular}{|c|c|c|c|c|}
\hline No & Aspect & Indicator & $\begin{array}{c}\text { Item } \\
\text { Number } \\
\text { of } \\
\text { Positive } \\
\text { Stateme } \\
\text { nt }\end{array}$ & $\begin{array}{c}\text { Item } \\
\text { Number } \\
\text { of } \\
\text { Negativ } \\
\text { e } \\
\text { Stateme } \\
\text { nt } \\
\end{array}$ \\
\hline \multirow{2}{*}{1} & \multirow{2}{*}{$\begin{array}{l}\text { Self- } \\
\text { Knowl } \\
\text { edge }\end{array}$} & $\begin{array}{l}\text { Recognizing } \\
\text { personal } \\
\text { qualities }\end{array}$ & 3 & 14 \\
\hline & & $\begin{array}{l}\text { Acknowledg } \\
\text { ing your } \\
\text { achievement }\end{array}$ & & 7 \\
\hline 2 & $\begin{array}{c}\text { Self } \\
\text { and } \\
\text { Others }\end{array}$ & $\begin{array}{l}\text { Seeing } \\
\text { things from } \\
\text { another } \\
\text { person's } \\
\text { perspective } \\
\text { and } \\
\text { developing } \\
\text { an } \\
\text { understandin } \\
\text { g of how } \\
\text { they might } \\
\text { see me. }\end{array}$ & 4 & \\
\hline
\end{tabular}

The specification of the self-esteem questionnaire is as presented in the following table.

TABLE 1. SPECIFICATION OF SELFESTEEM QUESTIONNAIRE 


\begin{tabular}{|c|c|c|c|c|}
\hline No & Aspect & Indicator & $\begin{array}{c}\text { Item } \\
\text { Number } \\
\text { of } \\
\text { Positive } \\
\text { Stateme } \\
\text { nt }\end{array}$ & $\begin{array}{c}\text { Item } \\
\text { Number } \\
\text { of } \\
\text { Negativ } \\
\text { e } \\
\text { Stateme } \\
\text { nt }\end{array}$ \\
\hline & & $\begin{array}{l}\text { Understandi } \\
\text { ng the } \\
\text { difficulties in } \\
\text { relationship } \\
\text { to cooperate } \\
\text { with others }\end{array}$ & & 16 \\
\hline \multirow{3}{*}{3} & \multirow{2}{*}{$\begin{array}{l}\text { Self- } \\
\text { accepta } \\
\text { nce }\end{array}$} & $\begin{array}{l}\text { Avoiding } \\
\text { self-criticism }\end{array}$ & 19 & \\
\hline & & $\begin{array}{l}\text { Comparing } \\
\text { with others }\end{array}$ & 10 & 5 \\
\hline & & $\begin{array}{l}\text { Accepting } \\
\text { that it is } \\
\text { natural to } \\
\text { make } \\
\text { mistakes }\end{array}$ & & 20 \\
\hline \multirow[t]{2}{*}{4} & \multirow{2}{*}{$\begin{array}{l}\text { Self- } \\
\text { relianc } \\
\text { e }\end{array}$} & $\begin{array}{l}\text { Building } \\
\text { self- } \\
\text { independenc } \\
\text { e }\end{array}$ & 13,15 & \\
\hline & & $\begin{array}{l}\text { Being able to } \\
\text { meet } \\
\text { challenges }\end{array}$ & & 8 \\
\hline 5 & $\begin{array}{l}\text { Self- } \\
\text { express } \\
\text { ion }\end{array}$ & $\begin{array}{l}\text { Understandi } \\
\text { ng how to } \\
\text { communicat } \\
\text { e with others }\end{array}$ & 17 & 1 \\
\hline \multirow[t]{2}{*}{6} & \multirow{2}{*}{$\begin{array}{l}\text { Self- } \\
\text { confide } \\
\text { nce }\end{array}$} & $\begin{array}{l}\text { Having a } \\
\text { strong belief } \\
\text { with your } \\
\text { ability }\end{array}$ & 18 & 6 \\
\hline & & $\begin{array}{l}\text { Being able to } \\
\text { make } \\
\text { decision }\end{array}$ & 12 & \\
\hline 7 & $\begin{array}{l}\text { Self- } \\
\text { awaren } \\
\text { ess }\end{array}$ & $\begin{array}{l}\text { Knowing } \\
\text { what I'm } \\
\text { capable of, } \\
\text { and setting } \\
\text { realistic } \\
\text { goals. }\end{array}$ & 2 & 9,11 \\
\hline \multicolumn{2}{|c|}{ Total } & & 10 & 10 \\
\hline
\end{tabular}

Before being given to the research sample, the questionnaire was administered in the try out test to find out the valid and invalid items. The validity calculation was done using Product Moment formula, while to test the reliability of the instrument the formula of Cronbach Alpha was used. From the test of validity and reliability, it was found twenty valid items out of 50 items tested. Then, the valid and reliable items were administered to the research subject to collect the students' data of selfesteem. The sample of the research consisted of 50 students taken by using simple random sampling technique. The data analysis from the questionnaire firstly will categorize the students' selfesteem into several categories. As it is stated by Azwar (2014) that the categorizing activity will place a group of individual in different level on the basis on certain continum. The categorization was done by using the following formula:

TABLE 2. CATEGORIZATION NORM

\begin{tabular}{|c|c|}
\hline $\begin{array}{c}\text { Norm/Scoring } \\
\text { Criteria }\end{array}$ & Category \\
\hline $\mathrm{X} \geq(\mu+1 \sigma)$ & High \\
\hline$(\mu-1 \sigma) \leq X<(\mu+1 \sigma)$ & Medium \\
\hline $\mathrm{X}<(\mu-1 \sigma)$ & Low \\
\hline
\end{tabular}

Description:

$\mathrm{X}$ : The score of the subject

$\mu$ (theoritical mean):

The theoritical mean of the maximum and minimum score

Deviation standard $(\sigma / \mathrm{sd})$ :

The range of spread data

The theoritical Maximum Score: The maximum score achieved based on scale calculation 
The theoritical Minimum Score: The minimum score achieved based on scale calculation.

The following result of the categorization was based on the students' self-esteem questionnaire consisting of 20 items:

The theoritical Maximum Score:

$5 \times 20=100$

The theoritical Minimum Score:

$1 \times 20=20$

Deviation standard $(\sigma / \mathrm{sd})$ :

$80 / 6=13,33$

$\mu$ (theoritical mean):

$(100+20) / 2=60$

Refering to the categorization formula, the research data in this research would be categorized on the basis of the following criteria:

TABLE 3. CATEGORIZATION NORM OF THE RESEARCH DATA

\begin{tabular}{|c|c|c|}
\hline $\begin{array}{c}\text { Norm/Scorin } \\
\text { g Criteria }\end{array}$ & $\begin{array}{c}\text { Norm/Scorin } \\
\text { g Criteria }\end{array}$ & $\begin{array}{c}\text { Categor } \\
\mathbf{y}\end{array}$ \\
\hline $\mathrm{X} \geq(\mu+1 \sigma)$ & $\mathrm{X} \geq 73$ & High \\
\hline $\begin{array}{c}(\mu-1 \sigma) \leq \mathrm{X}< \\
(\mu+1 \sigma)\end{array}$ & $47 \leq \mathrm{X}<73$ & Medium \\
\hline $\mathrm{X}<(\mu-1 \sigma)$ & $\mathrm{X}<47$ & Low \\
\hline
\end{tabular}

\section{Research Result and Discussion}

Having collected the data of students' self-esteem, it was then calculated to find out the score of selfesteem for each of the students. The data of students' self-esteem score is described in the following table.

TABLE 4. STUDENTS' SELFESTEEM

\begin{tabular}{|c|c|c|c|}
\hline No & $\begin{array}{c}\text { Interval } \\
\text { Score }\end{array}$ & Frequency & Percentage \\
\hline 1 & $34-42$ & 2 & $4 \%$ \\
\hline 2 & $43-51$ & 5 & $10 \%$ \\
\hline 3 & $52-60$ & 12 & $24 \%$ \\
\hline 4 & $61-69$ & 14 & $28 \%$ \\
\hline 5 & $70-78$ & 9 & $18 \%$ \\
\hline 6 & $79-87$ & 6 & $12 \%$ \\
\hline 7 & $88-96$ & 2 & $4 \%$ \\
\hline \multicolumn{2}{|r|}{ Total } & 50 & $100 \%$ \\
\hline
\end{tabular}

Next, the data were divided into several categories using the norm of deviation standard. The description of the students' self-esteem categories are as presented in the table 5 .

TABLE 5. THE CATEGORIES OF STUDENTS' SELF-ESTEEM

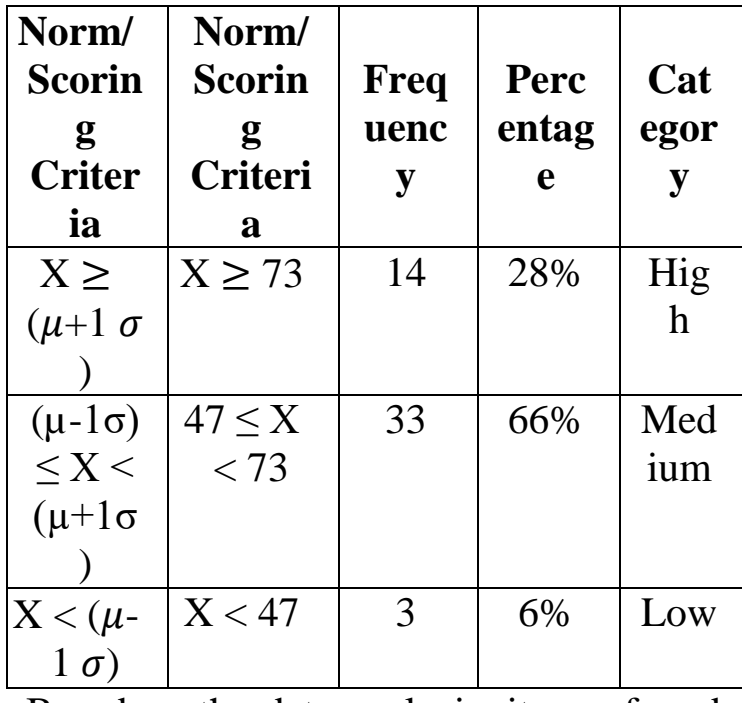

Based on the data analysis, it was found that most of the students' self-esteem of the first year students English Education 
Study Program belongs to medium category in which there are 33 out of 50 students or $66 \%$ percent students with medium self-esteem. It is also as described in the following diagram.

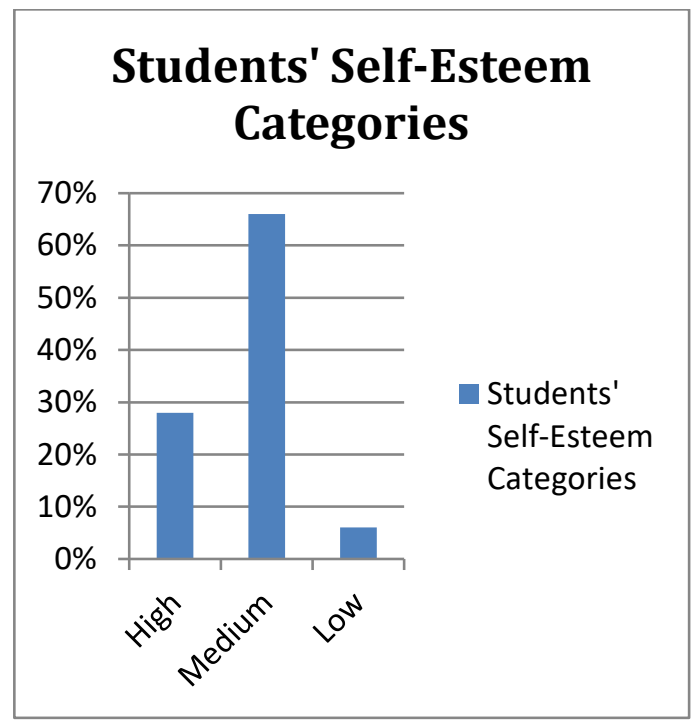

According to the research

finding, it is known that most of the students of the first year English Education Study Program in STKIP Muhammadiyah Kotabumi have maintained positive self-esteem within themselves. It can be seen from the research data showing that there are only $4 \%$ students' self-esteem which are categorized into low level of self-esteem, while the rest about $94 \%$ belong to high and medium level of self-esteem. There might be more reasons for how they can exhibit positive self-esteem. The role of their parents' involvement in giving much attention to their social interaction could have been one of the influential factors building their positive self-esteem as it is mentioned by Oswalt (2010). Additionally, other factors like good relationship with their peers and around, positive self-acceptance, or even the lecturers' teaching strategy also belong to several factors contributing to their positive self-esteem.

\section{Conclusion and Suggestion}

The research has found that most of the students of the first year English Education Study Program in STKIP Muhammadiyah Kotabumi exhibit positive level of self-esteem within themselves. It is then suggested to the lecturers teaching in this class to build positive atmosphere during the classroom activities as well as the outclass interaction in order that the positive self-esteem can be maintained. It is necessary for all related parties like the lecturers, their peers, parents, as well as they themselves to do more effort to keep the positive self-esteem as well as to help those who still in low self-esteem level move to the higher level of self-esteem. Due to the next researcher, it would be much more beneficial to do further research in relation with this research finding. Selecting and doing an experimental research relating to several methods to stimulate as well as keep 
poitive self-esteem can be one of the further beneficial insight of the research.

\section{References}

Azwar, S. 2014. Penyusunan Skala Psikologi. Yogyakarta: Pustaka Pelajar.

Brown, H. Douglas. 2000. Principles of Language teaching: Fourth Edition. New York: Addison weasley longman Inc.

Caunt, John. 2003. Boost Your SelfEsteem. London: Kogan Page.

Dhillon, Megha., Et all. 2016. Factors Influencing Self-esteem of Indian Female Adolescents. IOSR Journal Of Humanities And Social Science (IOSR-JHSS), Vol. 21 (7): $56-63$.
Mruk, Christoper J. 2006. Self-esteem Research, Theory, and Practice. New York: Springer Publishing Company.

Oswalt, Angela. 2010. Factors Influencing The Development Of Self-esteem, (daring), https://www.mentalhelp.net/articl es/factors-influencing-thedevelopment-of-self-esteem/, (25 Mei 2017).

Plummer, Deborah. 2005. Helping Adolescents and Adults to Build Self-esteem. London and Philadelphia: Jessica kingsley Publisher.

Schunk, Dale H., Paul R. Pintrich., Judith L. Meece. 2008. Motivation in Education: Theory, Research, and Apllications. New Jersey: Pearson Education, Inc., Upper Saddle River. 